\title{
AJARCDE

\section{Empowerment of Women's Farmer Groups of "Kembang Lestari" in the Processing of Organic Waste from Various Fruit Peels as Liquid Fertilizer}

\author{
A.A. Sagung Putri Risa Andriani ${ }^{1}$, Made Ayu Gemuh Rasa Astiti ${ }^{2}$, and Ni Ketut Sri Rukmini ${ }^{2}$ \\ ${ }^{1}$ Agrotechnology Study Program, Faculty of Agriculture, Warmadewa University. Indonesia \\ ${ }^{2}$ Animal Husbandry Study program, Faculty of Agriculture, Warmadewa University. Indonesia
}

\section{ARTICLE INFO}

Article History:

Received: 11 August 2021

Final Revision: 02 September 2021

Accepted: 30 September 2021

Online Publication: 01 October 2021

\section{KEYWORDS}

Woman's Farmer Group, Eco-Enzyme, environmentally friendly, organic waste, liquid fertilizer

\section{CORRESPONDING AUTHOR}

*E-mail: putri_risa69@yahoo.com

\section{A B S T $\mathbf{R}$ A C $\mathbf{C}$}

\begin{abstract}
Partners in the implementation of Community Service is the Kembang Lestari Peasant Women's Group located in Taman Village, Abian Semal Subdistrict, Badung Regency. This group has problems with the high price of chemical fertilizers and vegetable pesticides for the treatment of cultivated crops. This condition causes an increase in production costs and decreased profits. They have yet to find a solution to get cheaper, environmentally friendly plant-based fertilizers and pesticides that they will use in their organic farms in the future. Therefore, it is necessary to provide an alternative to organic fertilizers while serving as vegetable pesticides that are easy to make, cheap, and environmentally friendly. The alternative is an eco-Enzyme that can be made from organic waste in the form of fruit peels. Eco-Enzymes have the same benefits as liquid fertilizers, compost, anti-bacterial, midges, and disinfectants. Women's Farmer Groups of Kembang Lestari are given knowledge of eco-Enzymes and their benefits, how to make and how to apply them to plants. The methods carried out in the implementation of this activity are by interviewing, face-to-face, counseling, and practice methods directly. First, the authors held general counseling on what an eco-Enzyme is, its benefits for plants, and environmental sustainability. Second, the authors provide handson training in the manufacture of eco-Enzymes and how to implement them and conduct several evaluations to ensure farmers can make eco-Enzymes independently and see what percentage of the increased production and increased profits earned by the farmer group after the implementation of these eco-Enzymes. Third, it motivates farmers to keep using eco-Enzyme fertilizers continuously in cultivating crops.
\end{abstract}

\section{INTRODUCTION}

\subsection{Research Background}

The Women's Farmer Group "Kembang Lestari" consists of 30 people. This group is Located in Taman Village, Abiansemal Subdistrict, Badung. Geographically, the area of Taman village, Abiansemal District of Badung regency with a population of 6,859 people (2016) and an area of about $7.30 \mathrm{~km}^{2}$. Administratively, Taman village consists of 3 Indigenous Villages and 11 official Banjar. Banjar" is a social unit based on territory unity. This social unity is strengthened by custom unity and sacred religious ceremonies. The Women's Farmer Group of "Kembang Lestari" develops the Sustainable Food Yard program, intending to develop and empower the potential of the home yard so that it can help the family economy. The production costs incurred by this Group for the cultivation of food crops are felt quite high. Seeing this condition, universities through community service programs need to help groups of farm women utilize untapped organic waste into something that has a useful value known as eco-Enzymes. This activity is expected to be able to open the women's insights and educate women farmers to utilize household organic waste into something more useful. In addition, it can reduce the impact of environmental pollution and indirectly help the janitors in sorting household waste into organic and inorganic waste. Through this activity, it is also expected that the Women's Farmer Group can also be more creative and innovative in processing household waste in the future.

\subsection{Literature Review}

Eco-Enzyme is an organic solution produced by simple fermentation of fresh vegetable waste, fruit waste by the addition of brown sugar and water using selective microorganisms such as yeast and bacteria. The benefits of this eco-Enzyme can not only be used as liquid fertilizers, compost, anti-bacterial, midges but can add insight into environmental preservation [2]. Eco-Enzymes use raw materials that are easy to 
obtain and cheap. The type of waste used can come from household waste. The eco-Enzyme liquid is dark brown and has a strong sour/fresh aroma [3]. The fermentation process of ecoEnzymes takes 3 months. The resulting eco-Enzyme solution has a lot of properties. The use of eco-Enzyme pineapple skin exerts a good influence on the growth of chili peppers characterized by the height, diameter of the stems, the wider leaf width as well as the greener color of plants without eco-Enzyme fertilizers [4]. In the fermentation process alone, $\mathrm{O}_{3}$ gas (ozone) is needed by the Earth's atmosphere. An eco-enzyme solution when mixed with water can be used to water plants that will give you better fruit, flower, or harvest results [5].

\subsection{Research Objective}

This empowerment program aimed to improve the understanding of the women's farmer group about the benefits of fruit skin waste, train the manufacture of eco-Enzymes, and accompany the application of fertilizer products to plant growth. Methods used include counseling, direct practice, and mentoring that emphasize active group participation.

\section{MATERIALS AND METHODS}

\subsection{Method}

The method of implementing the activities of Utilization of Organic Waste into Eco Enzymes is to use:

1. Interview and discussion methods in finding out the problems experienced by partners.

2. Face-to-face and direct counseling method, so that partners get knowledge about the benefits of eco Enzymes and how to process organic waste into eco Enzymes.

3. Direct practice, guided by instructors who are competent in their field so that partners can directly apply the given methods.

\subsection{Plan and Procedure of Activities}

The community service plan and procedures to be implemented are:

1. Approach to the group, selection of places as well as selecting participants, who will then be referred to as trainees.

2. Interview and Q\&A about the problems faced by partners, as well as planning activities that show the steps of solutions to the problems faced.

4. Partners will first be given materials that have been prepared by the team in the form of modules on how to make some eco-Enzymes and their application to plants.

3. Direct application to farmers

4. If the implementation period of the activity will end, some supporting tools will be handed over for the manufacture of eco-Enzymes.

\subsection{Level of Participation}

a. Partners/trainees are expected to comply with all agreements that have been made.

b. The partner is expected to be disciplined and earnestly carry out all series of activities until all activity plans are ended.

c. After the community service activity ends the partner is expected to be able to make eco-Enzyme products that have the prospect to be marketed.

\subsection{The Outcome}

a. Farmers can produce eco-Enzyme products that are cheap, easy, and safe to the environment that serves as liquid fertilizers and midges.

b. Produced a small book/leaflet of Appropriate Technology about the manufacture of eco-Enzymes and how to apply them that is easy for the general public to understand.

c. The manufacture and application of eco-Enzymes and their impact on the cultivation plants of the Women's Farmer Group 'Kembang Lestari' will be published in the youtube media.

\section{RESULT AND DISCUSSION}

The implementation of community service activities in the Women's Farmer Group of Tani Kembang Lestari is located in Taman Village, Abian Semal Subdistrict, Badung Regency runs smoothly (Figure 1).

\subsection{Achieved Outcome}

The targets achieved from the activity are: (1) Partners can independently make eco-Enzymes and can apply them as organic liquid fertilizers and vegetable pesticides to vegetable crops; (2) Pest control of diseases with eco-Enzyme by $80 \%$; (3); Produce plants that are $100 \%$ organic due to the use of chemical fertilizers replaced with organic liquid fertilizers from eco-Enzymes; (4) The increase in production output is up to $30 \%$ due to the use of chemical pesticides replaced with vegetable pesticides from eco-Enzymes. In detail, the externality achieved from this community service activity can be seen in Table 1.

\subsection{Benefits}

\subsubsection{Environmental, Economic, and Social Impacts}

The implementation of this activity has an impact on the group of women farmers, namely the group can understand how to reduce organic waste and use it as an eco Enzyme. The group collects organic waste and makes eco-Enzyme independently. The ingredients used are fruit skin waste such as pineapple peel, orange peel, banana peel, guava, papaya skin as well as other vegetable and fruit waste. Eco-Enzymes made by the farmer group have been successfully seen from the $\mathrm{pH}$ value obtained, namely $\mathrm{pH}$ 3. Eco Enzyme has a low pH value due to its high organic acid content such as acetic acid or citric acid [6].

Reviewing the benefits to the environment, during the Enzyme fermentation process, 03 gas is produced which is a gas known as ozone [7]. Theoretically, if one content in Eco Enzyme is Acetic Acid $\left(\mathrm{H}_{3} \mathrm{COOH}\right)$, which can kill germs, viruses, and bacteria. While the Enzyme itself is Lipase, Trypsin, Amylase and can kill/prevent pathogenic bacteria. In addition, $\mathrm{NO} 3$ (Nitrate) and $\mathrm{CO}_{3}$ (Carbon trioxide) are also produced as nutrients. Economically, the manufacture of Enzymes can reduce consumption to buy floor cleaning fluids or insect exterminators [8].

The women's group can independently make eco-Enzymes and can apply them to vegetable crops as organic fertilizers and natural pesticides. Eco enzyme that is 1 month old has a high alcohol content so that it can treat plant pests, while eco Enzyme that is 3 months old can convert $\mathrm{CO}_{2}$ into $\mathrm{CO}_{3}$ (carbonate) that 
can nourish plants. Pest control of diseases with eco-Enzyme by $80 \%$ and an increase in production output up to $30 \%$ due to the use of chemical pesticides replaced with vegetable pesticides. In addition, the women's group of farmers produces $100 \%$ organic
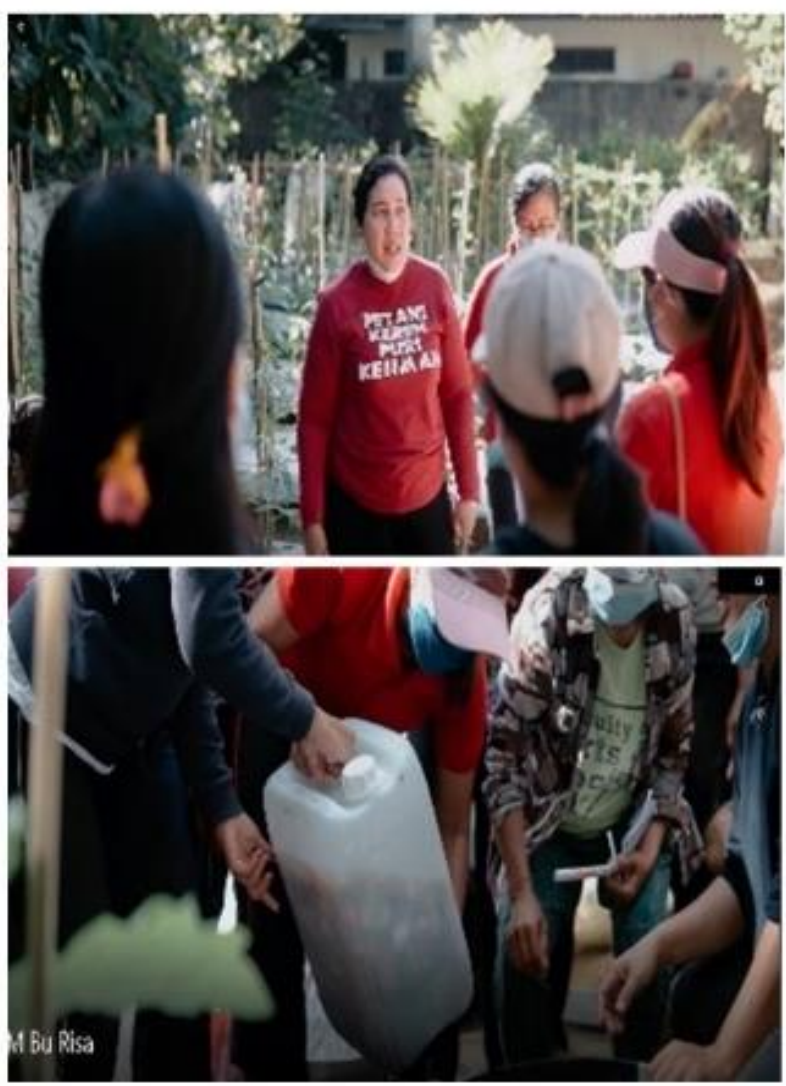

vegetables because the use of chemical fertilizers is replaced with organic liquid fertilizers from eco Enzyme.
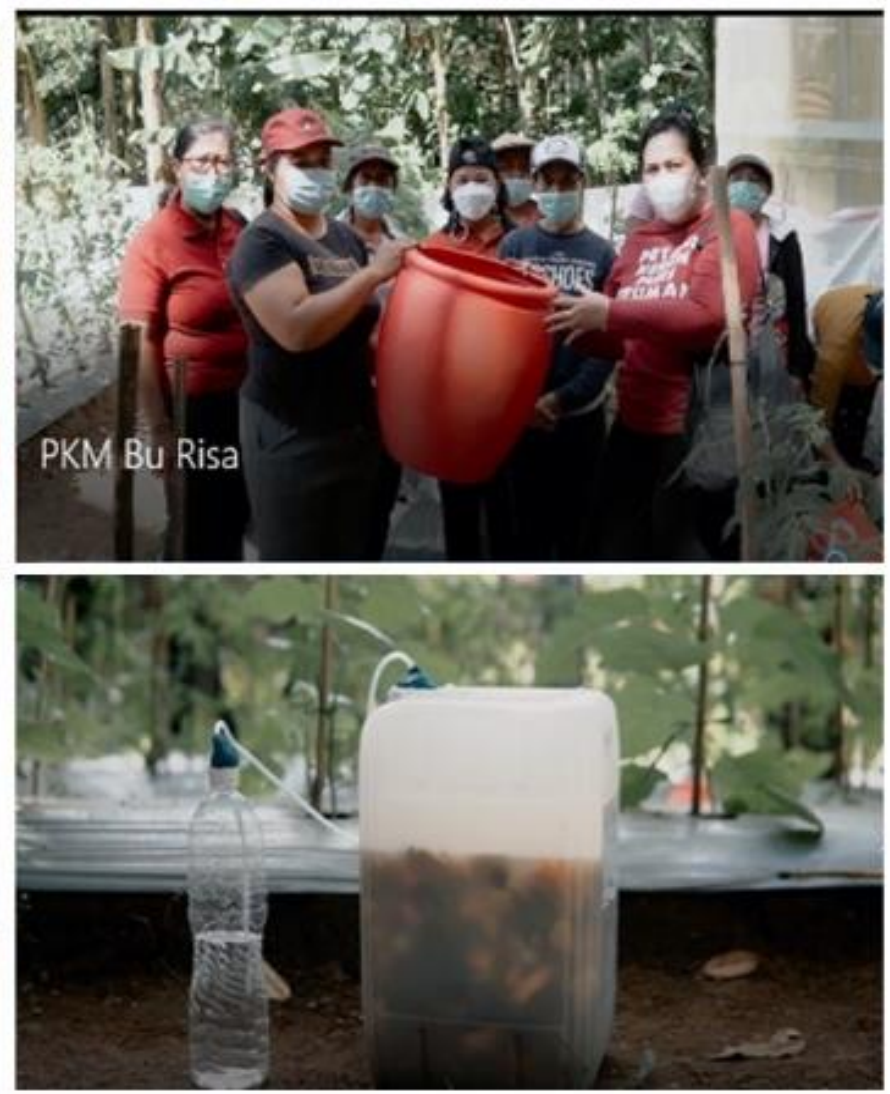

Figure 1. The implementation of eco-Enzyme manufacturing activities in the Women's Farmer Group of Tani Kembang Lestari is located in Taman Village, Abian Semal Subdistrict, Badung Regency

Table 1. Activities and activities output produced in the Women's Farmer Group 'Kembang Lestari ‘ Taman Village, Abiansemal District of Badung Regency

\begin{tabular}{|llll|}
\hline No & Activities & Output & Information \\
\hline 1 & $\begin{array}{l}\text { Counseling and Providing } \\
\text { Materials on The } \\
\text { Manufacture of Eco- } \\
\text { Enzymes }\end{array}$ & $\begin{array}{l}\text { Extension material in the form of } \\
\text { leaflets }\end{array}$ & $\begin{array}{l}\text { The Women's Farmer Group already understands the } \\
\text { material on Eco-Enzyme Manufacturing }\end{array}$ \\
\hline 2 & $\begin{array}{l}\text { Direct Practice of Eco- } \\
\text { Enzyme Manufacturing }\end{array}$ & Eco-Enzyme products & $\begin{array}{l}\text { The Women's Farmer Group has been able to make } \\
\text { Eco-Enzyme }\end{array}$ \\
\hline 3 & $\begin{array}{l}\text { Application of Eco- } \\
\text { Enzyme in Plants }\end{array}$ & $\begin{array}{l}\text { The Peasant Women's Group has } \\
\text { directly applied eco-Enzyme made by } \\
\text { itself to plants as liquid fertilizers and } \\
\text { pesticides. }\end{array}$ & $\begin{array}{l}\text { The Farmer Group has applied Eco-Enzyme correctly } \\
\text { according to the right dosage and concentration. } \\
\text { 1-month-old eco Enzyme is used as a pesticide and 3- } \\
\text { month-old eco Enzyme is used as a liquid fertilizer }\end{array}$ \\
& & \\
\hline
\end{tabular}

The manufacture of this Enzyme has a broad impact on the environment globally and in terms of economics.

\subsubsection{Partner contribution to the executor}

Community Partnership Program activities regarding the manufacture of eco-Enzyme and its application to vegetable crops have been running smoothly in the Women's Group of Tani Kembang Lestari Taman Village, Abiansemal Subdistrict
Badung Regency. The first activity was held on Saturday, May 8,2021 , in the form of counseling or theoretical studies to provide an understanding of the material on how to make eco Enzyme attended by 20 people from the Group of Women Tani Kembang Lestari. The second activity held on Sunday, May 9, 2021 , is in the form of direct practice of making eco Enzyme and the extension team also contributes tools and materials for the manufacture of eco Enzyme. The third activity held on Saturday, June 12, 2021, is the application of eco Enzyme in plants as pesticides and liquid fertilizers. All partners (100\%) 
actively follow the direct practice in activities and partners expect continuous assistance in the manufacture of eco Enzyme.

\subsection{Inhibiting Factors of the Implementation of Community Service}

Factors that inhibit the implementation of the program, the inhibiting factor is the condition of the Covid-19 Pandemic. This condition makes it difficult to find a schedule for the implementation of activities.

\subsection{Supporting factors}

The farming group is very careful to know how to make ecoEnzymes and how to apply them to plants. The ingredients used in the manufacture of eco-Enzymes are easy to find, namely fruit and vegetable skin waste.

\subsection{Solutions and follow-ups}

The obstacles faced in the implementation of the community services program can be overcome by communication with the chairman of the group and village officials. Direct counseling and practice activities can take place smoothly by the Health protocol of covid-19 prevention.

\subsection{Future Plan}

Furthermore, the team will continue to assist in the production of eco-Enzyme and its application. The plan is that in addition to producing eco-Enzyme for group purposes, the next plan is also expected that the group can sell eco-Enzyme to other farmers.

\subsection{Strategic steps for further realization}

Strategic steps to realize the next plan are to provide hands-on practice on packaging techniques and provide the right marketing strategy to market eco-Enzymes.

\section{Conclusion}

Community service has been carried out successfully and smoothly. Women's farmer groups can independently make eco-enzymes and can apply them to vegetable crops. Pest control of diseases with vegetable pesticides by $80 \%$ and an increase in production output by $30 \%$ due to the use of chemical pesticides replaced with vegetable pesticides. Vegetable crops are produced $100 \%$ organic because they use organic fertilizers from eco-enzymes. The use of eco-enzymes is very profitable, in addition to being environmentally friendly can also reduce production costs so farmers are advised to use eco-enzymes.

\section{REFERENCE}

[1] Hetal Ashvin Kumar Mavani, In Meei Tew, Lishen Wong, Hsu Zenn Yew, Alida Mahyuddin, Rohi Ahmad Ghazal, and Edmond Ho Nang Pow. Antimicrobial Efficacy of Fruit Peels Eco-Enzyme against Enterococcus faecalis An In Vitro Study, International Journal of Environmental Research and Public Health, 13 July 2020.

[2] Hemalatha, H. and P.Visantini, ((2020). Potential use of eco-Enzyme for the treatment of metal-based effluent. IOP Conf. Series: Materials Science and Engineering 716, 1-6

[3] Aisyah Hadi Ramadani, Reny Rosalina, Riska Surya Ningrum. "Pemberdayaan Kelompok Tani Dusun Puhrejo Dalam PengolahanLimbah Organik Kulit Nanas Sebagai Pupuk Cair Eco-enzim". Prosiding Seminar Nasional HAYATI VII, 2019.

[4] Suswanto Ismadi Megah S, Desi Surlitasari Dewi, Eka Wilany. "Minda Baharu". Pemanfaatan Limbah Rumah Tangga Digunakan Untuk Obat dan Kebersihan, Volume 2, No 1 Juli 2018, E-ISSN 2614-5944.

[5] Etienne, A., Genard, M., Lobit, P., Mbeguie-Ambeguie, D. \& Bugaud, C.( 2013) What controls fleshy fruit acidity? A review of malate and citrate accumulation in fruit cells. Journal of Experimental Botany, 64(6), 14511469

[6] Rubin, M.B. (2001). The History of Ozone. The Schonbein Period, 1839- 1868. Bull. Hist. Chem. 26 (1) : 71-76

[7] Eviati \& Sulaeman. (2009). Analisa Kimia Tanah, Tanaman, Air Dan Pupuk. Bogor : Badan Penelitian Dan Pengembangan Pertanian Departemen Pertanian. 